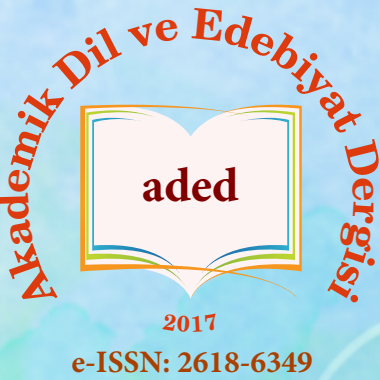

\author{
Akademik Dil ve Edebiyat Dergisi \\ Academic Journal of Language an literature \\ Cilt: 3, Sayı: 1, (Nisan 2019)
}

\title{
Ayşegül Çelik’in “Haziran Dilekleri” Hikâyesi Üzerine Bir Tahlil Denemesi
}

\author{
An Analysis On Ayşegül Çelik's Story "Haziran Dilekleri"
}

\section{Hilal GÜNDÜZ BALOĞLU *}

*YL Öğrencisi, Ankara Hacı Bayram Veli Üniversitesi

e-mail: hllgunduz8@gmail.com

Araştırma Makalesi / Research Article Article DOI: https://doi.org/10.34083/akaded.539807

Sorumlu Yazar / Corresponding Author

Hilal Gündüz Baloğlu, Ankara Hacı Bayram

Veli Üniversitesi, Ankara / Turkey

\section{ORCİD : 0000-0002-6263-520X}

Geliş Tarihi / Received : : 14.03.2019

Kabul Tarihi / Accepted : 02.04.2019

\section{Atıf / Citation}

GÜNDÜZ BALOĞLU, Hilal (2019). Ayşegül Çelik'in "Haziran Dilekleri” Hikâyesi Üzerine Bir Tahlil Denemesi. Akademik Dil ve Edebiyat Dergisi, 3 (1), 96-103.

DOI: 10.34083 /akaded.539807

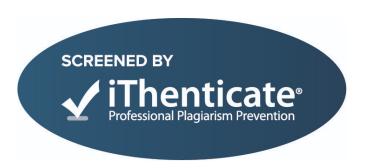

Öz

Bu makalede yazarın kurgusal dünyasını yansıtması sebebiyle "Haziran Dilekleri" hikâyesi tahlil edilmiştir. Hikâyeleriyle ödüller almış bir yazar olan Ayșegül Çelik'in hikâyelerine dair makale düzeyinde bir yayının olmaması hasebiyle yazarın hikâyeci yönü "Haziran Dilekleri" hikâyesi üzerinden yansitılmak istenmiștir. "Haziran Dilekleri" hikâyesinin tahlilinin yapıldığı bu makalede, makaleye ana çatı oluşturması bakımından, giriş kısmında yazarın hayatına, eğitimine, ödüllerine ve hikâye kitaplarılla birlikte hikâyelerinin ismine değinilmiştir. Ayrıca giriş kısmının içerisinde "Haziran Dilekleri" hikâyesinin yer aldığı Sehper, Dehlizdeki Kus adlı hikâye kitabına dair de bazı tespitler yapılmıștır. "Haziran Dilekleri” hikâyesi Prof. Dr. Mehmet Tekin'in Roman Sanatı 1 kitabı ve Doç. Dr. Abdullah Harmancı'nın "Hüseyin Rahmi Gürpınar'ın Öyküleri ve Öykücülüğü" adlı doktora tezinden hareketle konu, olay örgüsü, anlatıcı ve bakış açısı, kişiler, zaman, mekân, dil ve üslup, anlatım teknikleri olmak üzere sekiz başlık altında tahlil edilmiştir. Bu başlıklara kısaca bakacak olursak hikâyenin konusunda Hidırellez kutlamalarına yer verilir ve bu durumun sebebi yazar tarafından halk için önemli bir unsurun okuyucuya yansıtılmak istenmesidir. Olay örgüsünde yazarın Hıdırellez kutlamalarını, kişiler üzerinden aktarmasında kopmaların yaşanması hikâyenin akıcılığını etkiler. Anlatıcı ve bakış açısı bölümünde ise ben anlatııılarda olan eksik yön "Haziran Dilekleri" hikâyesindeki birinci kiși anlatıcıda da görülür ve bu durumun giderilmesi için birinci kişi anlatıcının hikâyedeki diğer kişilerin gözünden verilme yöntemi yazar tarafından uygulanmaz. Hikâyenin başkişi dışında kalan "kişiler kadrosu"nun yardımcı kişi statüsünde olması kurgulamada yazarın tercihidir. Hikâyede yazar zaman mefhumuna dair bilinçli bir kırılma olușturur. Hikâyedeki açık ve kapalı mekânların kișiler üzerinde farklı etkiler oluşturması kurmaca yapının daha iyi yansıtılmasını sağlar. Hikâyede aynı zamanda kahraman anlatıcı olan bașkișinin konumuna uygun konușturulması hikâyenin gerçekçi yönünü besler. Anlatım tekniklerinden laytmotif tekniği kullanılarak "Haziran Dilekleri” hikâyesi ile Şehper, Dehlizdeki Kuş kitabındaki diğer hikâyeler arasında bağlantı kurulur. Bu makalenin sonuç kısmında ise tahlilden hareketle "Haziran Dilekleri" hikâyesine dair değerlendirmeler yapılmıştır.

Anahtar Kelimeler: Ayşegül Çelik, hikâye, "Haziran Dilekleri”, tahlil

\begin{abstract}
In this article, the story of "Haziran Dilekleri" was analyzed because it reflects the author's fictional world. Because of the lack of a publication at the article level about the stories of Aysegül Celik, an author whose stories received awards, the narrator aspect of the writer has been tried to be reflected through the story of "Haziran Dilekleri". As it provides a basis for the article, the author's life, education, awards, the story names with the story books have been mentioned in the introduction section. In addition, some findings were made about the story book Şehper, Dehlizdeki Kus which contains the story of "Haziran Dilekleri" in the introduction. The story of "Haziran Dilekleri" has been analyzed under eight chapters, based on the book Roman Sanati 1 by Prof.Dr. Mehmet Tekin and Associate Professor Abdullah Harmanci's PhD thesis titled "Hüseyin Rahmi Gürpinar's Short Stories And Storytelling", such as: subject, plot, narrator and point of view, persons, time, place, language and style, and narrative techniques. If we look at these topics briefly, Hidirellez celebrations are included in the story's subject and the reason of this situation is that the author wants to reflect an important event for the public to the reader. Because the author conveys the celebrations of Hidirellez through the individuals, there are ruptures in the plot and this affects the fluency of the story. In the narrator and point of view section, the missing aspect of the first-person narrators is also seen in the story of "Haziran Dilekleri", and to remedy this situation, the method of telling the first-person narrator through the eyes of others in the story is not applied by the author. In the story, it is the author's preference in the editing that the persons other than the protagonist are in the status of an assistant person. In the story, the author creates a conscious break in the notion of time. The fact that the open and closed places in the story create different effects on the people provides a better reflection of the fictional structure. In the story, making the protagonist, who is also a hero-narrator, speak in a proper way nourishes the realistic aspect of the story. Using the "leitmotif" narrative technique, a link between the "Haziran Dilekleri" story and other stories in the book Șehper, Dehlizdeki Kus is established. In the conclusion part of this article, evaluations were made about the "Haziran Dilekleri" story based on the analysis.
\end{abstract}




\section{Giriş}

Ayşegül Çelik, 24 Haziran 1968 tarihinde Ankara'da doğar. Hacettepe Üniversitesi İktisadi ve İdari Programlar ile Ankara Üniversitesi Dil ve Tarih- Coğrafya Fakültesi, Tiyatro bölümlerinde okur. Hacettepe Üniversitesinin Sosyal Antropoloji Bölümü’nün yüksek lisans programına girer. Yazın hayatına, Sensizankaradadenizdüşleri (1997) adlı şiir kitabıyla başlar. Öykü, şiir ve makaleleri; Varlık, Milliyet Sanat, Hürriyet Gösteri, kitap-lık, Doxa, Bütün Dünya, Akşam-lık, Kent ve Gençlik, Bireşim, "ağır ol bay düzyazı", Dünden Bugünden Edebiyat gibi dergilerde okuyucuyla buluşur. Cumhuriyet, Hürriyet, Milliyet, Star, Radikal, Yeni Şafak, Sabah gibi gazetelerde ise röportajları çıkar. Sinema, sahne ve televizyon için drama ve çocuk programı yazarlığı yapar. Radyo oyunlarıyla TRT'den ödüller alır. Hüseyin Rahmi Gürpınar'ın romanından uyarladığ 1 oyun, Devlet Tiyatroları ve Bursa Şehir Tiyatroları'nda sahnelenir. Devlet Opera ve Balesi Modern Dans Topluluğu, Librettosunu yazdığı Arda Boyları'nı sahneler. Belki Varmış Belki Yokmuş(2003),Kadın Öykülerinde Ankara(2008), Şehir ve İnsan(2010),Kadın Öykülerinde Doğu(2011), Bir Dersim Hikâyesi(2012),Kar İzleri Örttü(2012), Alice Harikalar Diyarı'ndan Tüymüş Bulunuyor (2013) isimli derleme öykü kitaplarında hikâyeleriyle yer alır. Yazarın ilk hikâye kitabı Korku ve Arkadaşı'nı (2005); Şehper, Dehlizdeki Kuş (2008) ve Kâğıt Gemiler (2010) hikâye kitapları izler. Notre Dame de Sion Edebiyat Ödülleri'nde mansiyon ödülünü, Şehper, Dehlizdeki Kuş adlı hikâye kitabıyla; Yunus Nadi Öykü Ödülü’nü 2010 yılında Kâğıt Gemiler adlı hikâye kitabıyla alır. Ankara Üniversitesi Devlet Konservatuarı'nda, bir süre, Dünya Edebiyatı ve Uygarlık Tarihi derslerine girer. Alice Harikalar Diyarı'ndan Tüymüş Bulunuyor adlı çok yazarlı hikâye kitabını yayına hazırlar. Muhsin Ertuğrul'un hayatını anlattığı kitabı: Ölmeyi Bilen Adam Muhsin Ertuğrul 2013 yılında Can Yayınları tarafından yayımlanır. (www.canyayinlari.com.tr, 2019)

Ayşegül Çelik'in ilk hikâye kitabı Korku ve Arkadaşı, Yapı Kredi Yayınları tarafından 2005 yılında yayımlanır. Daha sonra Can Yayınları tarafından Kasım 2013'te bir baskısı daha yapılır. Yirmi bir hikâyeden oluşan bu kitabın içerisindeki hikâyeler şunlardır: "Korku ve Arkadaşı", "Tarçın", "Incili Gece”, "Atlar ve Avcılar", "Safran”, "Gecesefası", "Suretler ve Gölgeler”, "Sarı Şarkı”, "Diken ve Kordela", "Korku ve Arkadaş", "Yok Hikâye”, "Kar Ağacı", "Bitek Toprak”, "İçeriden Sızan Işık", "Balçık Çiçeği”, "Nağme”, "Kuşlar, Balıklar ve Cümle Mahlukat", "Pantili”, "Gümüş Gecelik", "Kumsal", "Şenlikçi”.

Ayşegül Çelik’in ikinci hikâye kitabı Şehper, Dehlizdeki Kuş; Yapı Kredi Yayınları tarafından 2008 yılında yayımlanır. Daha sonra Can Yayınları tarafından Kasım 2013'te bir baskısı daha yapılır. Şehper, Dehlizdeki Kuş on altı hikâyeden oluşur: "Gerçeküstü", "Sudaki Halkalar", "Kiralık Gelincik", "Bebek Evi”, "Haziran Dilekleri”, "Pusula”, "Kaptan Flint'in En Gizli Hazinesi”, "Tutanak", "Böcek”, "Pembe Gülün Laneti”, "Yağmur Işığı", "Sarı Kuzgun”, “Kör Peri”, "İnce, Gümüş Çerçeve ve Simler”, “Su Kırılıyor Adnan”, “Anahtarı Kendinden Menkul Kapılar”.

Ayşegül Çelik'in üçüncü hikâye kitabı Kâğıt Gemiler, Yapı Kredi Yayınları tarafından 2010 yılında yayımlanır. Daha sonra Can Yayınları tarafından 2013 ve 2015 yıllarında iki baskısı yapılır. Kâğıt Gemiler, on hikâyeden oluşur: "Afsun”, "Kuşlar, "Kelimeler Masalı", "Gökteki Kara Boncuk", "Toprağın Hikâyesi”, "Beyaz Kelebekler”, "Çöl Gemileri”, “Ah, Seni Bahtsız Yalnız", "Deli Orman", "Son Hikâye".

Tahlil edilecek olan "Haziran Dilekleri" hikâyesi, Şehper, Dehlizdeki Kuş adlı hikâye kitabının beşinci hikâyesidir. Şehper, Dehlizdeki Kuş’taki hikâyelerin kurguları birbiriyle bağlantılıdır. Yazar, okuyucunun bu birlikteliği bulmasını ister. Hikâyelerde geçen ögeler birbirini çağrıștırır. 
Hikâyelerin hepsinde "lunapark" önemli bir yer tutar. Yazarın hikâyelerinde, herkesin ayrı bir lunaparkı ve dönme dolabı vardır. Kahramanlar, burada hayatları ve seçimleriyle var olur.

"Haziran Dilekleri” hikâyesinin tahlilinde Prof. Dr. Mehmet Tekin'in Roman Sanatı 1 kitabı ve Doç. Dr. Abdullah Harmancı'nın "Hüseyin Rahmi Gürpınar'ın Öyküleri ve Öykücülügü̈” adlı doktora tezindeki hikâyeleri tahlil planı ölçüt alınmıştır. Hikâye; konu, olay örgüsü, anlatıcı ve bakış açısı, kişiler, zaman, mekân, dil ve üslup, anlatım teknikleri olmak üzere sekiz başlık altında incelenecektir.

\section{Konu}

"Haziran Dilekleri” hikâyesinde, yazarın hikâyenin isminden içeriği okuyucuya sezdirdiği görülür. Hikâyenin konusu; haziran ayına yakın zamanlarda, İzmir'de, on iki yaşındaki kız çocuğunun ve mahalle sakinlerinin toplanıp Hıdırellez'i kutlamasıdır. "O zamanlar Hidırellez bir şenlik İzmir'de... Gece, ağzımızda büyüyor; çünkü sırlar var damağımızı zorlayan, Hızır'ın ev ev, bahçe bahçe gezeceği vakte hazırlanıyoruz. Birazdan dilekler asılacak gül dallarına. Dilekler: Gizli hevesler." (Çelik, 2013: 41-42)

Ayşegül Çelik, bu hikâyesinde halk için önemli bir kutlama olan Hıdırellez'e yer verir. Bu konudan hareketle Hıdırellez'le ilgili çalışmalara bakılacak olursa Prof. Dr. Erman Artun'un “Türk Halk Kültüründe Hıdırellez" adlı makalesinde Hıdırellez'in Türk toplumundaki ehemmiyeti görülür: "Hıdırellez, ortak kültürel değer olması yönüyle önemli bir yere sahip olup Türklük dünyasında ve Anadolu'da ortak inanmalarla, ortak heyecanlarla yüzyıllardır kutlanılmaktadır... Hıdırellez bahar bayramı niteliğinde kutlanan mevsimlik bayramlarımızdandır. Türk kültürü içinde canlılığını koruyan geleneklerden biri de 'Hıdırellez'dir. Hıdırellez geleneği, bir bayram olarak bütün Türk milletinin topluca katıldığı, kutladığı, bir takım töreleri yerine getirdiği bir bahar bayramıdır. Bu tarih, kışın bitişi yazın başlangıcı, olarak kabul edilir. Rûz-1 Hızır (Hızır’ın günü) olarak adlandırılan Hıdırellez günü, Hızır ve İlyas sözcükleri birleşerek halk ağzında Hıdırellez şeklini almıştır." (www.turkoloji.cu.edu.tr, 2019)

\section{Olay Örgüsü}

"Haziran Dilekleri" hikâyesi, başkişinin yıllar geçtikten sonra on iki yaşındayken kutladıkları Hıdırellez'i hatırlamasıyla başlar. Mahalleli, Hızır’ın evlerde, bahçelerde gezeceğini düşünerek gül dallarına dileklerini asmaya hazırlanır. İnsanların dileklerindeki maddi yön, başkişiye farklı gelir. Dileklerinin kabul olması için ateş yakmaya çalışırlar ve oğlanlar kızlara "çalım atar". Aklı, aşağı mahalleden Özgecan'dadır, mahalleliler ise en büyük ateşi yakma yarışındadır. Başkişinin en yakın arkadaşı Şule de Özgecan'a âşıktır. Şule'yle aralarında güzelliğe ve resim dersine dair sırlar vardır. Şule'nin annesinin intiharından sonra tanışırlar. Şule, alevlerin üstünden atlayarak dileğini gül dallarına asmaya gider. Bu sırada başkişi herkesin dağılmasını bekler ve Özgecan’ın dileğini merak ettiği için bahçedeki güllerin yanına gider. Özgecan'ın dileğini ararken Şule'nin ve mahallelinin dileklerini okur: "Görünüşe göre herkes doktor olmak ve villalarda oturmak istiyor. Bir kişi hariç: Şule. Şüphesiz, bu onun kâğıdı. Sarsak yazısını tanıyorum. Şule, Hızır'dan iki şey diliyor; bir annesini bir de büyük aşkının kendisini sevmesini, Özgecan'ın.” (Çelik, 2013: 44) Burada başkişinin büyüdügü zamanki düşüncelerine geçilir ve bu geceki olayları hatırladığı için kendisine kızar. Okuduklarından sonra "ateşi", "geceyi" ve "Hıdırellez"i sevmediğini söyler. Evlerine doğru ilerlerken aklına Özgecan'ın da Şule’yi dilemiş olabileceği gelir ve korkarak dileklerin asıldığ 1 güllerin yanına tekrar gelir. Özgecan'ın dileğini ararken diğer dilekleri yırtıp atar. Bir gölgenin geldiğini fark etmesi üzerine bahçeden kaçar ama aklında Şule'nin dileğini yırtamaması ve Özgecan'ın dileğini bulamaması kalır. Annesi rahatsızlandığı için iki ay sonra başka şehre taşınırlar. Taşınmalarının üzerinden iki sene geçtikten sonra ise annesi ölür. Onun aklında 
annesinin Şulelerin evinin annesi olduğu düşüncesi vardır. Şule ve Özgecan'ın evlendiklerine ve her sene Hıdırellez zamanı birbirlerini düşündüklerine inanır.

"Haziran Dilekleri” hikâyesinin olay örgüsünde, ara ara kopmaların olduğu görülür. Özgecan ve Şule'nin hikâyeye dâhil olduğu kısımda kişiler tanıtılmak istendiği için olay örgüsünde kopma yaşanır. Burada Şule ve başkişinin arkadaşlıklarına ve Şule'nin annesinin ölüm hadisesine yer verildiği için, okuyucu Hıdırellez kutlamalarından uzaklaşır. Yazarın kişileri tanıtma amaçlı yaptığı bir kesintidir: "Kardeşi yok Şule’nin, annesinin intiharından sonra üç katlı bir evde babasıyla yalnız yaşıyor. Bizden biraz yukarıda oturuyorlar. Annesi ölmeden önce onlara hiç gitmemiştim. Zaten gidişimin nedeni de bu intihardı. Ölümün kışkırtıcıllğı önüme düşüp ince ince sorular sordurmuştu bana." (Çelik, 2013: 43)

Hıdırellez Bayramı’nın olay örgüsünde kişiler üzerinden iyi yansıtıldığı görülür. Ayşegül Çelik, bu hikâyede Hıdırellez'le ilgili yaygın inançlara yer verir. Nedim Bakırcı, "Hıdırellez ve Niğde'de Unutulan Bir Gelenek: Niğde Cumaları" adlı makalesinde Hıdırellez'in gelmesiyle birlikte Anadolu'daki hazırlıklara değinir: "Anadolu'da 5 Mayısı 6 Mayısa bağlayan gece bazı hazırlıklar yapılır. Bu hazırlıklar arasında evlerin içi ve dışı yani bahçesi temizlenir. Ayrıca evlerde boya badana yapılır. Çünkü Hıdırellez günü Hz. Hızır’ın evlerini ziyaret edeceğine, eğer evler temiz olmazsa evlere Hz. Hızır’ın uğramayacağına inanılır. Aile büyükleri kendilerine, çocuklarına yeni elbiseler, ayakkabılar ve çoraplar alırlar. Herhangi bir renk tercihi yapılmaksızın giyim seçilir, ancak bazı yörelerde Hz. Hızır'ın beyaz giydiğine inanıldığı için beyaz renk elbise tercih edilir. Hıdırellez törenleri için akşamdan yemekler hazırlanır. Ayrıca Hıdırellez kutlamaları için çeşitli hayvanlar kurban olarak kesilir." ( www.turkishstudies.net, 2019) Hikâyedeki kişiler de Hızır'ın evlerini gezip dileklerini yerine getireceğini düşünerek bütün gün boyunca hazırlık yapar.

Hikâyedeki kişilere, olaylar ekseninde anlatının yapısına uygun olarak yer verilir. Berna Moran, yazarın edebi eserde uygulaması gereken bu durumu Edebiyat Kuramları ve Eleştiri kitabında açıklar: "Yazar bir adamın hayatını günü gününe en ince ayrıntısına kadar anlatsa sanat yapmış olmaz... Bunun için de anlatmak istediğinin özüne ait olmayan unsurları, ayrıntıları, rastlantısal olanları atar, gerekli olanı ayıklar, seçer ve bunlar arasında bir bağ gözeterek olaylar örgüsünü bir tek çizgi üzerinde kurar. Seçme işi hem esere yapı bakımından bir birlik hem de insan dünyasıyla ilgili bir anlam sağlar." (Moran, 2012: 29)

\section{Anlatıcı ve Bakış Açısı}

Birinci kişi anlatıcı tarafından anlatılan "Haziran Dilekleri” hikâyesinde tekil bakış açısı kullanılır. Hikâyenin başkişisi İzmir' de oturdukları zamanlara gider ve kendisiyle birlikte mahallesini anlatır. “ (Ben) anlatıcı, anlatı dünyasının içindedir ve bu durum, onun için adeta bir kaderdir. (Ben) anlatıcı, (O) anlatıcı gibi anlatı dünyasının içinde, üstünde ve hatta dışında bulunma gibi bir lükse, güce sahip değildir. Onun dünyası, anlatı çevresinde kurgulanan dünyadır ve bu dünyada o, hem 'anlatan' hem de 'anlatılan' figür konumundadır." (Tekin, 2010: 41) Birinci kişi anlatıcının eksik yönü "Haziran Dilekleri” hikâyesinde de göze çarpar. Hikâyenin başkişisine dair dışarıdan bir gözlem olmadığ için, okuyucu kahramanın kendisini anlattığı kadar onu tanıyabilir.

Hikâyenin başkişisi, ileri bir tarihten on iki yaşındaki zamanlarını anlattığı için çocukluk dünyasına farklı bir gözle bakar. "Bir köşede ince dalları kırıp ateşe hazırlayan şu salkım saçh kız benim herhalde. Çünkü yanımda o plastik şişe var; ince belli, mavi blendaks. Parmaklarıma sinen gaz yağı kokusundan hemen tanıyorum kendimi. Ha, bir de gözlerimden... On iki yașındayken, iki kirpik arasında olup biten bütün mucizeler vakayı adiyeden... Bu iki kirpik arasından her zaman aşklar uçuşur, her zaman Körfez görünür zannediyorum. Bütün mucizelerden habersiz bir alay çocuğuz. O vakitler büyüklerin sokaktaki Hıdırellez’e bakıp ne düşündüğ̈̈nü bilemiyoruz. Bunu otuz 
dört yaşında, gecenin aklına uyup gittiğimiz lunaparkta, belli belirsiz seçeceğiz.” ( Çelik, 2013: 42) Burada yazar tarafından, hikâyenin başkişisinin hayatının iki ayrı devresinde yaşadığı benlik farklılığ ayrışan dönemler şeklinde okuyucuya hissettirilir.

\section{Kişiler}

"Haziran Dilekleri” hikâyesindeki kişiler; başkişi, Şule, Özgecan ve mahallenin diğer sakinleridir. Hikâyede başkişinin ismine yer verilmez. Modern romanla birlikte roman ve hikâyelerde isimsiz karakterler görülmeye başlanır. Nathalie Sarraute'nin kahramanın ismiyle birlikte kahramanın yaşadığı değişime bakış açısı dönemin anlayışını gözler önüne serer: "Eskiden her şeyi vardı; çeşit çeşit eşyâlarla şımartılmıştı; özel bakımlarla kuşatılmıştı, donunun gümüşî kıvrımlarından burnunun ucundaki süslü pertavsıza kadar hiçbir şeyi eksik değildi. Zamanla her şeyini yitirdi: Atalarını, özenle yapılmış, bodrum katından tavan arasına kadar çeşitli eşyâlarla tıklım tıklım doldurulmuş evini, en değersiz incik boncuğuna kadar her şeyini, irad senetlerini, giysilerini, bedenini, yüzünü ve her şeyden önemlisi, sadece kendine özgü olan kişiliğini, ismine kadar her şeyini...” (Sarraute, 1985: 38) Kahramanların okuyucunun bulunduğu dünya düzenine göre değişmesi olağan bir durumdur. Her çağın insanının beklenti ve yaşama biçimlerinin edebi eserlere de doğrudan etki etmesiyle devinim yaşanır çünkü insanoğlu sunduklarının karşı tarafın süzgecinden geçmesini canı gönülden bekler.

Mahalle sakinleri, Şule ve Özgecan hikâyedeki yardımcı kişilerdir. Hikâyede mahalle sakinlerinin ve Özgecan'ın ismi sadece başkişi tarafından zikredilir, bu kişiler hikâyenin içerisinde kendi kişilikleriyle aktif değillerdir. Şule ise hikâyenin bir kısmında annesinin intiharıyla ilgili sorulara verdiği cevaplarla yer alır, bu durum haricinde başkişinin tanıttı̆̆ kadar bilinir. Nurullah Çetin'in Roman Çözümleme Yöntemi kitabında yardımcı kişilerle ilgili yaptığı açıklamalar mahalle sakinlerinin, Şule'nin ve Özgecan'ın "Haziran Dilekleri” hikâyesindeki durumunu gösterir: "Bu kişiler, tip ve karakter özellikleriyle görünmeyen, olayın ya da dekorun tamamlanmasında kendilerine ihtiyaç duyulan ve zaman zaman ortaya çıkan yardımcı unsurlardır. Genellikle ya isim olarak ya da kendilerine verilen kısa görevleriyle ortaya çıarlar.” (Çetin, 2013: 165) Şerif Aktaş’in tasnifine göre bu kişilere bakıldığında ise Şule, Özgecan ve mahalle sakinleri "dekoratif unsur durumundaki kahramanlar" dır. Şerif Aktaş, Roman Sanatı ve Roman İncelemesine Giriş kitabında bu kahramanların özelliklerini şu şekilde açıklar: "Tiyatro ve sinemada figüran rolündeki oyuncular gibi anlatma esasına bağlı edebî eserlerde, mahallî rengi aksettiren, dikkatlere sunulmak istenen vaka ve vaka parçasına ait tablonun gözler önünde daha iyi tecessümüne hizmet eden şahıslar da vardır. Bunların vaka içinde yüklendikleri herhangi bir fonksiyon yoktur, eserde psikolojik hususiyetlerinden söz edilemez." (Aktaş, 2005: 142)

Hikâyenin başkişisi, aynı zamanda anlatıcı konumunda olduğu için hikâyenin tam merkezindedir. Başkişi, yaşadığı andan on iki yaşındaki hâline bakar ve o zamanki düşüncelerinin sebebini idrak eder: "On iki yaşındayım. Dilekleri tamamlayan haziran çiçeklerinin vakitsizce baş verip geceden çıktığını, ters dönüp aklıma açıverdiğini fark edemiyorum.” (Çelik, 2013: 45) İnsanın olayları yaşadığı zamanda anlamlandırması güçtür, geçen yıllarla birlikte geçmişin maddi manevi etkileri kişi tarafından anlaşılabilir veya hiçbir zaman çözülemez. Bu durumdan hareketle yazar başkişinin düşüncelerinin zihni dünyasını olumsuz etkilediğini çiçeklerin açış yönüyle okuyucuya yansıtmıştır.

\section{Zaman}

"Haziran Dilekleri” hikâyesinde iki ayrı zaman vardır. Hikâyenin başkişisinin yaşadığı gün ve geçmişte on iki yaşında kutladıkları Hıdırellez Bayramı zamanıdır. Başkişinin yaşadığı günün 
zamanı da haziran ayına yakın vakitlerdir. "Mevsimler değişiyor; yaz geldi mesela, işte haziran yanı başımızda duruyor. Takvimler olmasa, saatler... Bihaberiz hazirandan." (Çelik, 2013: 41) Hikâyede zaman dilimi olarak mevsim önemli bir yer tutar.

Hikâyenin başkişisinin tam olarak kaç yaşında olduğu hikâyede söylenmediği için zamanda ne kadar geriye gidildiği bilinmez. Birinci kişi anlatıcı, hikâyenin bir yerinde otuz dört yaşındaki halinden bahsettiği için yaş olarak daha ileri bir tarihte olduğu düşünülür. Başkişinin on iki yaşında olduğu Hıdırellez kutlamalarından en az yirmi iki yıl geçer.

Hikâyede başkişinin ve ailesinin İzmir'den taşınması Hıdırellez kutlamalarından iki ay sonra gerçekleşir. Taşındıklarının üzerinden iki yıl geçtiğinde de annesi ölür. Hikâyenin bu kısmında iki sayılarının art arda kullanılması hikâyedeki gerçekçiliği kırar. Yazar tarafından bu durum bilinçli olarak yapılmıştır ve böylece okuyucuya gerçek dünyanın dışında kurmaca bir dünyada olduğu hissettirilir.

\section{Mekân}

"Haziran Dilekleri” hikâyesinde mekân olarak bahçe, Şule'nin evi, aşağı sokak, başkişinin evi, İzmir ve ismi söylenmeyen diğer şehir vardır. Hikâyenin geneli, Hıdırellez kutlamalarından dolayı bahçelerde geçer. Şule'nin tanıtıldığı bölümde mekân olarak Şule’nin evi gösterilir. Bahçe dışındaki diğer mekânlar, yazar tarafından dekor olarak kullanılır. Bu mekânların üzerinde durulmaz. İzmir, olayın geçtiği şehir olarak tanıtılsa da mekân perspektifinden İzmir'e dair bir bakış yoktur.

Hikâyede mekânlar arası geçiş hızlıdır. Hem açık hem de kapalı mekânlar kullanılsa da olayların cereyan ettiği yer bahçedir. Mekânlar içerisinde Şule'nin evi, başkişinin iç dünyasındaki ölüm sorunsalını göstermek amacıyla yer alır; hikâyede kahramanın ağzından da ölüm kışkırtıcı olarak nitelenir. Böylece kahramanın iç dünyası hayatın olmazsa olmazlarına karşı sorgulama içerisindedir. Aşağ 1 sokak ve başkişinin evi kişiler üzerinde etkili değildir, arka fon konumundadırlar. Bahçe hikâyedeki kişilerin hepsinin bir araya geldikleri tek mekândır ve açık bir mekân olmasına rağmen kahramanlar, herkesten saklı tuttukları dileklerini gül ağacının dallarına asmayı tercih eder. $\mathrm{Bu}$ durumun nedeni ise yazar tarafından hikâyedeki kişilerin arasındaki kurmaca yapının oluşturulmasının amaçlanmasıdır. Hikâyenin başkişisinin bahçede ikilemde kaldığı görülür çünkü sevdiğinin ve arkadaşının dileği herkesin bahçeyi terk etmesiyle birlikte ulaşabileceği bir konumdadır. Başkişi dileklere teker teker baktığında Şule'nin Özgecan'ı dilediğini görmesi onda sevdiklerinden uzaklaşma duygusu yaratır ve Özgecan'ın dileğinde de Şule'nin olabileceği düşüncesi duygu karmaşası yaşamasına sebep olur. Özgecan'ın dileğini bulamaması başkişiyi büyük bir çlkmaza sürükler, zihni dünyasında Özgecan ve Şule’ye dair çıkarımlar yapar ve bu durumdan geçen zamana rağmen kurtulamaz. "Yillar geçti; ne Şule'den haber aldım ne Özgecan'dan. Sanırım evlenmiştir onlar... her Hıdırellez'de birbirlerinden gizli beni düşünmektedirler. Benim gibi.” ( Çelik, 2013: 46) Böylece yazar tarafından başkişinin bu bahçede yaşadıkları ömrü boyunca unutamayacağı saplantılı bir duruma dönüştürülür. Bahçede yaşananlar insanoğlunun yaşadıklarının zihni dünyasındaki etkisine yazarın bir bakışıdır. Şule ise hikâyede dileğini astığı gül ağacıyla birlikte varlığını okuyucuya hissettirir. Ayrıca, yazarın Şehper, Dehlizdeki Kuş kitabındaki diğer hikâyelerle de bağlantı kurmak için "Haziran Dilekleri” hikâyesinde lunaparkı kullandığı görülür. Bu hikâyede, kitaptaki diğer hikâyelerin aksine lunapark önemli bir yer tutmaz. Yazarın bu ögeyi, çağrışım kurma amacıyla, bilinçli olarak hikâyede kullandığı düşünülür.

\section{Dil ve Üslup}


"Haziran Dilekleri” hikâyesindeki birinci kişi anlatıcının dilinin sade olduğu görülür. Hikâyedeki anlatıcının dili konumuna uygundur. Çünkü hikâyenin başkişisi yıllar sonraki bir zaman diliminden on iki yaşındaki hâlini anlatır. Başkişi ile Şule'nin diyaloğunda kahramanlar yaşlarıyla uyumlu konuşturulur. Yazar, hikâyesinde konuşma dilini yakalamak istediği için deyimleri ve devrik cümleleri kullanmayı tercih eder.

Genel olarak değerlendirildiğinde yalın ve eleştirel üsluba yer verildiği görülür. Şimdiki zamanda anlatıcı konumunda olan başkişi tarafından yalın üslup kullanıldığı için on iki yaşındaki çocuğun duyguları okuyucuya geçer. Hikâyedeki eleştirel üslup ise mahallelinin dileklerinin maddi yönünedir: "Dilekler: Gizli Hevesler. (Tuhaf değil mi herkesten saklanan başıboş dileklerin bir peygambere itirafı? Çünkü uygunsuz şeyler bunlar. Çoğu açlık ve tamahın payandasında yükseliyor, kıskançlık ve kin biriktiriyor içinde: Çocuğum doktor olsun, mühendis olsun, çok zengin biriyle evlensin, villalarda yaşasın inşallah! )" (Çelik, 2013: 42) Yetişkinlerin hep daha iyi konumlarda olma isteği çocuk dünyası içerisinde anlamlı değildir. Yetişkinlerin ve çocukların hayattan beklentileri aynı düzlemde yer almaz çünkü insanoğlunun hayata dair bakış açısı dönemlere göre değişiklik arz eder. Burada aynı zamanda iyi konumda olmanın doktor veya mühendis olmak ve villada oturmakla ilişkilendirilmesi toplumun bu bilinç yapısında olduğuna dikkat çekmek içindir.

\section{Anlatım Teknikleri}

Şehper, Dehlizdeki Kuş kitabındaki diğer hikâyelerden hareketle bu hikâyede de "leitmotiv" tekniğinin kullanıldığı görülür. Şehper, Dehlizdeki Kuş’taki hikâyelerin genelinde "lunapark", "mavi", "dönme dolap" ve "yıldız" kelimeleri geçer. Ayşegül Çelik, hikâyeleri arasında bağlantı kurarak kahramanları için bu kelimeleri anlamlı hale getirir. Bu hikâyede ise "lunapark" ve "mavi" kelimelerine yer verilir. "Haziran Dilekleri” hikâyesinin devamı olarak kurgulanan "Pembe Gülün Laneti” hikâyesinde de "yıldız" ve "dönme dolap" kelimeleri göze çarpar. Mehmet Tekin, laytmotif tekniğinin bu yönünü şöyle açıklar: "Bir romanda sık sık tekrarlanan söz grubu, herhangi bir dize, yine konu veya kişilerle ilgili olarak tekrarlanan bazı kelimeler de 'leitmotiv' olarak kabul edilmelidir." (Tekin, 2010: 252)

Hikâyede kullanılan diğer bir anlatım tekniği de diyalogdur. Başkişi ile Şule arasında geçen kısa diyalog olay örgüsünde kopmaya neden olur. Başkişi, Şule'nin annesinin intiharını merak ettiği için Şule'ye sorular sorar ve ondan aldığı cevaplara göre intihar anını canlandırmaya çalışır. Hikâyenin bu kısmında diyalogla birlikte, az da olsa, gösterme tekniği kullanılır.

"Haziran Dilekleri" hikâyesinde tasvir tekniği de kullanılır. Tasvir tekniğinden sadece iki cümlede yararlanılır. Bu cümlelerde başkişi ve Özgecan belirgin özellikleriyle tanıtılır: "Ben bütün kızların en uzunuyum; hiçbir çalıma gelemem. Özgecan da en esmer gözlüsü oğlanların.” (Çelik, 2013: 42) Yazar, kahramanın göz renginin koyuluğunu ifade etmek için kara kelimesi yerine esmer kelimesini tercih eder. Yazarın, okuyucunun dikkatini kahramanın üzerine çekmek için "esmer" kelimesini kullanım dışında uyguladığı görülür.

\section{Sonuç}

Hikâyede başlık içerik uyumu görülür. Ayşegül Çelik'in diğer hikâyelerinin genelinde de başlı̆̆ın içerikle olan uyumundan dolayı, yazarın başlık içerik ilişkisini bilinçli yaptığı bir uygulama olarak düşünebiliriz. Yazarın toplumda karşılığı olan Hıdırellez kutlamalarına hikâyesinde yer vererek hayatın kurmacasını okuyuculara yansıtmak istediği görülür.

Yazarın hikâyelerini incelediğimizde, hikâyelerde isimsiz kahramanlara yer verildiğini tespit ettik. $\mathrm{Bu}$ tespitle birlikte "Haziran Dilekleri" hikâyesindeki başkişinin de isimsiz olmasının yazar 
tarafından bilinçle tercih edildiğini söyleyebiliriz. Hikâyenin birinci kişi anlatıcı tarafından anlatılması ve başkişisinin isimsiz olması, okuyucunun hikâyeyle özdeşleşmesini sağlar.

Hikâyenin olay örgüsünün bazı yerlerinde kopmalar yaşansa da kurgu anlamında genel olarak güçlüdür. Hikâyenin anlatıcısı birinci kişi olduğu için başkişinin tanıtılması eksik kalır. Okuyucu, kahramana dışarıdan bir gözle bakamadığı için başkişiye dair ayrıntılı bilgilerden yoksundur. Hikâyedeki "kişiler kadrosu" sınırlıdır ve mahalle sakinleri, Özgecan, Şule hikâyede dekor olarak yer alır. Bu kişilere hikâyede söz hakkı verilmemesi hikâyenin gerçekçi yönünü kırar.

"Haziran Dilekleri” hikâyesinde bahar mevsimini yaşayan İzmir'e dair mekân tasvirleri yoktur. Yazar, eski bir anlatım tekniği olan tasvire hikâyesinde yer vermek istemediği için İzmir'le mevsimi ilişkilendirmemiştir. Yalın bir üslupla yazılan bu hikâyede ayrıntıya fazla girilmemiştir. Ama hikâye genelinde kahraman- okuyucu özdeşleşmesi sağlandığı için okuyucunun gözüne çarpan bir durum değildir. Yazar, anlatım tekniklerine kahramanlarını tanıtmak amacıyla yer verir. Laytmotif tekniğiyle hikâyeleri arasında bağ kurarak kahramanları birbirine yaklaştırır.

Ayşegül Çelik'in eserlerinin genel yapısını incelediğimizde hikâye kitaplarındaki hikâyeler arasında bağlantı olduğunu tespit ettik. Bu bağlantı sayesinde hikâyeler birbirine 1şık tutar ve kapalı kalan yerler açıklığa kavuşur. "Pembe Gülün Laneti" hikâyesi, "Haziran Dilekleri" hikâyesinin devamı niteliğindedir. "Pembe Gülün Laneti"nde ise aynı kişilere ve olaylara dair başka bakış açıları ve kurgulama vardır. Bu tespitlerden hareketle, yazarın; olayları ve durumları okuyucunun idrak edip çözmesini istediği düşünülür.

\section{Kaynakça}

Aktaş, Şerif. (2005). Roman Sanatı ve Roman İncelemesine Giriş. Ankara: Akçağ Yayınları.

Artun, Erman. "Türk Halk Kültüründe Hıdırellez". http://turkoloji.cu.edu.tr/HALKBILIM/erman_artun_turk_halk_kulturunde_hidrellez.pd f [Erişim Tarihi: 12.03.2019]

Bakırcı, Nedim. "Hıdırellez ve Niğde'de Unutulan Bir Gelenek: Niğde Cumaları”. http://www.turkishstudies.net/Makaleler/1619798472_41bakırc1_nedim.pdf [Erişim Tarihi: 12.03.2019]

Çelik, Ayşegül. (2013). Şehper, Dehlizdeki Kuş. İstanbul: Can Yayınları.

Çetin, Nurullah. (2013). Roman Çözümleme Yöntemi. Ankara: Öncü Kitap.

Harmancı, Abdullah. (2010). Hüseyin Rahmi Gürpınar’ın Öyküleri ve Öykücülüğü, Doktora Tezi, Konya: Selçuk Üniversitesi.

İnternet: Ayşegül Çelik, https://canyayinlari.com/kisidetay/yazarlar/12455/aysegul-celik [ Erişim Tarihi: 25.02.2019]

Moran, Berna. (2012). Edebiyat Kuramları ve Eleştiri. İstanbul: İletişim Yayınları.

Sarraute, Nathalie (1985). Kuşku Çağı (Çev. B. Kösemihal). İstanbul: Adam Yayınları.

Tekin, Mehmet. (2010). Roman Sanatı 1. İstanbul: Ötüken Neşriyat. 